Josip Brumec

Faculty of Organization and Informatics

UDC: 007.5

Varaždin

Original Scientific Paper

E-mail: Josip.Brumec@foi.hr

\title{
Strategic Planning of Information Systems
}

\begin{abstract}
Strategic planning of information systems (IS) has lately become an interesting subject for both the researches and practitioners dealing with IS-development and information technologies (IT) implementation in business systems. Recent researches have shown that the impact of IT on the effectiveness of business systems is less than has been expected. Therefore, information systems development and information technology implementation can not be solely the problem for system analysis and IT professionals, but also one of the most important problems for top management. The hypothesis that the efficiency of ITimplementation depends on strategic planning of information system has been set in this paper. In order to improve the efficiency of the investments in IT, some new proposals and guidelines are given.
\end{abstract}

Keywords: strategic planning, information system, information technology.

\section{Current state in estimating IT efficiency in business systems}

There is still a very apparent disagreement between management and system analysts about what a good information system is. What IS/IT professionals consider to be a good IS is the one developed on the most recent ITs. Having primarily in mind hardware (computers, communication equipment) and software (programming languages DBM-systems, CASE-tools) or even some modern operational IS concepts (structural or object-oriented approach, client/server, ODBC and similar). Generally, they think that providing the latest available equipment is company's good investment. Software and hardware manufacturers have imposed the so-called cost/performance approach, whose economic defficiency can't be noticed by strictly technically-oriented IS/IT professionals. Equipment has its economic value only it its use is clearly defined in advance and the potential profit that its use will bring to the company is known.

On the other hand a pragmatic company management is well aware of the fact that better investment is the one that brings higher profit in the medium-term, at the same time insuring long-term stability and more favourable market position for further growth and development. Therefore the primary criterion for the estimation of each investment is the so-called profitability rate and the most important thing when deciding about investment is finding the most favourable cost/benefits proportion.

The main question arising when you make investments in IS/IT, is not the one about the contradiction of these two criteria, but the order in which they follow each 
other. System analysts and IT professionals must accept the fact that their criterion is only a subgroup of the criteria that management uses, while management must persist in estimating investments into IT in the similar way accepted for all other investments in manufacturing and business technologies, in other words, according to the profitability of the investment. There is no rational. reason why not estimating the investment in IT in the same way as any other investment although, up to the present time is mostly hasn't been carried out this way, neither in our country nor abroad. Cook and Parish, for example, have found that $70 \%$ IS/IT investment projects are not based on investment profitability calculation, while Peppard (1993) is astonished at the fact that a great number of top managers doesn't have the slightest vision of how to make use of IT for improving the main activities and achieving company's development stability (here not referring to personal use of computer and common word-processing, spreadsheets programs etd.). As for IS/IT professionals the situation is even worse. The researches carried out by Grindley for example, point to the fact that even $83 \%$ of information managers in companies are concerned only with the technical side of IS and simply don't want to deal with the problems of IT investment profitability. Such situation in the field of IS/IT strategic planning and the firm intention to change the current state, is often described in literature with one frequently quoted sintagma: "informatics is too important to let it be handled by system analysts and IT professionals only" which is a paraphrase of a well-known G. Clemenceau's maxim: "war is too serious matter to be left over to generals only".

First serious signs that the effect of IT application was below expected were given by Morrison and Berndt (1990) in their paper presented at the annual conference of the American Association of Economists. The briefest conclusion, called "paradox effect" reads: the bigger IT investment, the smaller productivity increase". Description of this problem was given by Krakar (1996) although the topic had already been described in the similar way Brumec (1995a). That's the reason why more and more university researchers are focusing their work on this problem which is resulting in a great number of researches and papers on IS strategic planning and the profitability of IT investment. IT's a very complex problem that a great number of authors deal with like for example Earl (1989), Hochstrasser (1990), Griffiths and Willcocks (1994), Willcocks (1994), Currie (1995), Ward and Griffiths (1996), Robson (1997) etc.

Therefore our IS/IT professionals also have to be ready, in a very near future, to give an answer to a very logical question posed by management: is it, for example, and why better to invest $500000 \mathrm{Kn}$ in information equipment and IS/TT experts than into qualified turner and his machine or maybe car and business administrator? On the other hand the management of the company has to accept their responsibility for future IS development and IT investment and have the feeling of being competent because management is not expected to make decisions related to ITs, but those related to appropriate use of ITs.

The knowledge that will enable both sides (management, IS/IT professionals) to play there roles in IS development strategic planning with full responsibility, is much 
broader than it can possibly be described within this paper, but to put it briefly we can say that it includes the following groups of measures:

- carrying out simultaneously IS development strategic planning and company's development planning, including the annual renewal of long-term planning;

- examining business objectives, processes and company's business technology conforming to the principles of business process reengineering (BPR, Hammer, 1993) and managing necessary changes;

- applying modern design methods and techniques (structural and object-oriented) in IS development by using CASE-tools for as many states of IS life cycles as possible;

- taking measures for permanent raising of company's organizational maturity and creating positive attitudes towards accepting new IT.

For a start, with firm intention to improve the current state, IS/IT professionals must find the way to make IS development and IT investment part of the overall strategy planning of a company, which will be the topic of further discussion.

\section{Definition of IS strategic planning}

There is no unequivocal definition of the notion "strategic planning of information systems" in a very extensive literature that covers this field. So, we'll try to give the definition by considering the separate definitions of the notions that are part of this sintagma.

The notion of business strategy has been described by numerous authors like, for example, Ansoff (1965), Mintzberg (1979), Quin and Mintzberg (1991), Johnson and Scholes (1993), Robson (1997) and others. Summarising the essence of the material written by the mentioned authors we could say the following: Strategy is making decisions about the time and the way of using the overall company resources, based on the estimation of the possibility of achieving the set goals in a period of several years. According to the preceding definition, strategic planning is reconciling overall company resources and conditions that company faces in its environment and call conforming to accepted strategy. The third notion defined by Brumec in his paper (1996) reads: Information system is a subsystem of an organisation whose task is to link processes at the operational, management and decision-making level in order to improve operational efficiency, good-quality management support and decisionmaking duality. Finally, the following definition, based on the works of the mentioned authors can be given: IS strategic planning is a long-term planning of IS useful effects and the use of IT in management, and all within the scope of strategic development planning of a business system as a whole.

Besides this formal definition, attention should be given to changes that have happened, over a period of time, in the basic content of the organisation's strategic planning, which is shown in Figure 1. Only strategic vision answering the questions 
like: how to get the best technology and how to have the lowest costs or how to carry out business processes in as short time as possible, will guarantee companies future existence and development.

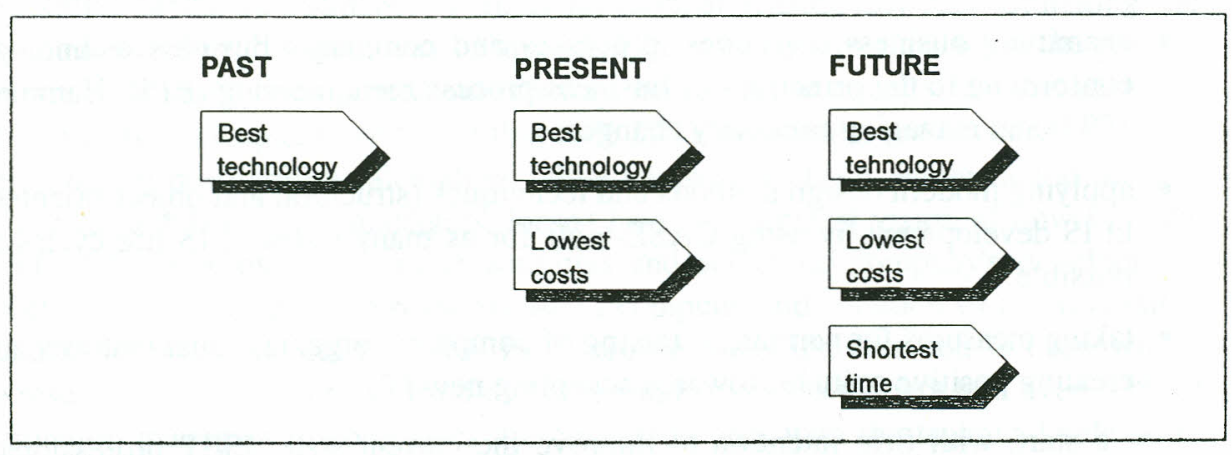

Figure 1: Change in the content of organisation's strategic planning

Previous figure implies that it's necessary to examine the future influence of information technologies, because they are the only factor that can meet the requirements of the third demand, in other words, quarantee the shortest time in performing business processes. On the other hand, as the second section of this paper will show, the IS development planning parameters and the use ITs are resulting from the strategic development planning of a company. Therefore, it is obvious that the strategic development planning and IS planning of a company, must be carried out as united process. Some steps in this process may differ, because of the use of some specific planning methods and techniques but the unity of the process must always be respected.

\section{Approach to IS strategic planning and the use of IT}

According to the definition, given in the previous section, we should examine strategic planning of IS development in organisation as two separate, although mutually dependent, stages: defining IT strategy. Reasons are of methodical nature, since different methods and techniques are used in planning and designing these two strategies, but also because of the fact that IS strategy holds the first place in the hierarchy. While IT strategy starts with activities and deals with information resources (hardware and software equipment and its application) IS strategy starts with business objectives and deals with entire resources. This includes equal examination of the use of conventional and computer technologies and communications, approach to IS development as well as organisational measures for managing entire business processes.

It is necessary to draw attention to two more characteristics of SPIS that seem to be the logical result of the previous definition: 
- SPIS is carried out within the strategic planning of business system development and

- it is renewed every year, always for a long-term period (5 to 6 years, for example)

There are many reasons why SPIS should be carried out in this way, and here we give only some of them:

- IS/IT investment is very expensive: from $2 \%$ (for heavy industry) to $8 \%$ (for stock market) out of the annual gross income, according to the results of some researches;

- Efficient IS and profitable IT use may be a critical factor for further existence of a company;

- Suitable IS becomes a strategic weapon for most companies: it can enable competitive advantage, increase in productivity, new organisation in managing business activities and the development of new business areas:

- Designing a suitable IS depends on many factors: market, competition, suppliers, customers, manufacturing technologies, business partners, state regulation etc.

Relation between business strategy and IS/IT strategy is shown in Figure 2 which strongly emphasizes the characteristic which emerges from the previous definition: SPIS must result from organisation's business strategy. Accepting this simple but very far-reaching fact is the principal presumption for modern approach to IS development in which IS represents organisation's business technology and is the condition for selection the suitable IT for designing IS.

In figure 2 , it is important to notice that the influence of ITs must be estimated at the stage of a long-term business strategy planning, but not as a separate element when selecting technological principles of IS. According to this, development of ITs has only indirect influence on IT strategies to be selected by management in order to achieve their strategic goals. Organisation's business strategy creates guidelines for IS strategy which is the basis for defining business technology and IS that will support this business strategy. Further, IS strategy determines IT strategy because IT is only a technical business infrastructure.

Strategic development plan should determine the potential importance of IT and computer supported IS for a particular organisation. There are some objective criteria for doing this while disharmony between objective importance and IS/IT professional's subjective feelings can provoke many frustrations and be the reason for unsuccessful application of ITs, purchased without respecting this element. More objective estimation of the importance of IS and planned ITs for a company, can be made by using redesigned matrix /known as Boston quadrangle) designed by McFarlan (1984). For this purpose two elements should be examined: 
a) Influence of IS/IT on the result of business performance (or to what extent the result of business actions, measured by standard economic indicators, like profit-rate on invested capital, depends on IS and ITs on which IS is built);

b) Operational dependence on IS/IT (to which extent are operational functions of organisation dependent on the level of used IT).

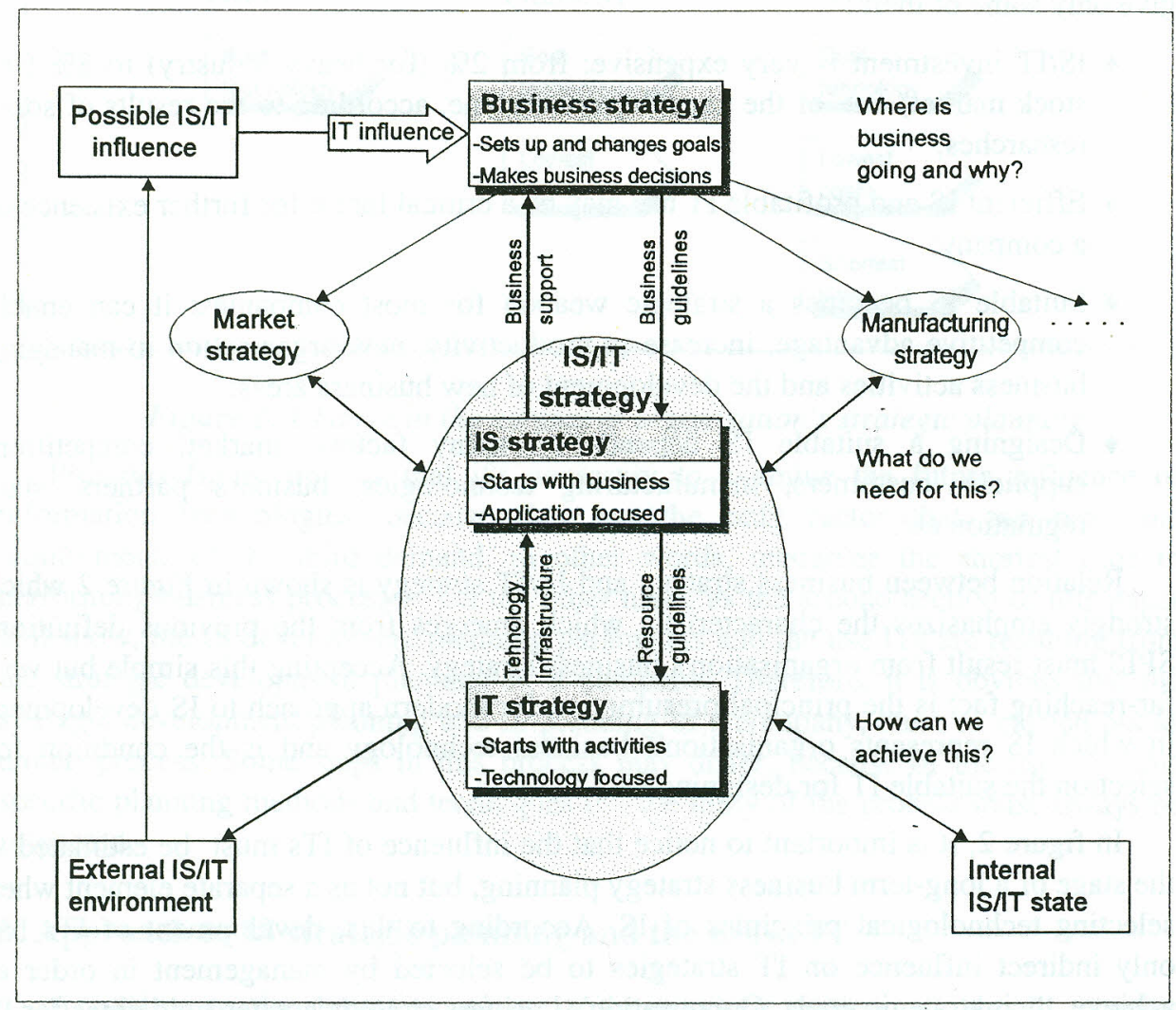

Figure 2. Relation between business, IS and IT strategy

Placing these two factors on two orthogonal axes of co-ordinate system and presenting each of them by two discrete levels (low or high influence and small and great dependence) we get the matrix as the one shown in Figure 3.

Based on two-factor and two-level analysis, shown with matrix, Figure 3, four principal IS types could be determined, regarding the degree of the impact of new ITs (used for IS design) on a particular organisation. We could name them, under certain conditions, as following:

- SUPPORTING: modern IT in such organisation could have some effects but it is not decisive for current and future development. Cement industry is a typical 
example. Advice for the management in this case could be: invest into new ITs on the condition that you covered all other investment needs.

- OPERATIONAL: modern IT is necessary for doing a competitive business, but no significant, direct increase in business economy can be expected. As a typical example stands machine-tool industry which cannot respond in time to market challenges without computer supported design or keeping work orders.

- POTENTIAL: By implementing modern ITs organisation of such type can achieve competitive advantage. An insurance company, for example, by introducing distributive system for direct drawing up of insurance policy (with the possibility of performing such activities by the representative of a company, on a portable computer at the house of a client) will acquire such market position that will insure them competitive advantage.

- STRATEGIC: If the strategy of organisation depends on IS it must permanently invest into ITs, otherwise it won't be able to organise profitable business managing nor can expect survival or development. Typical example are air companies.

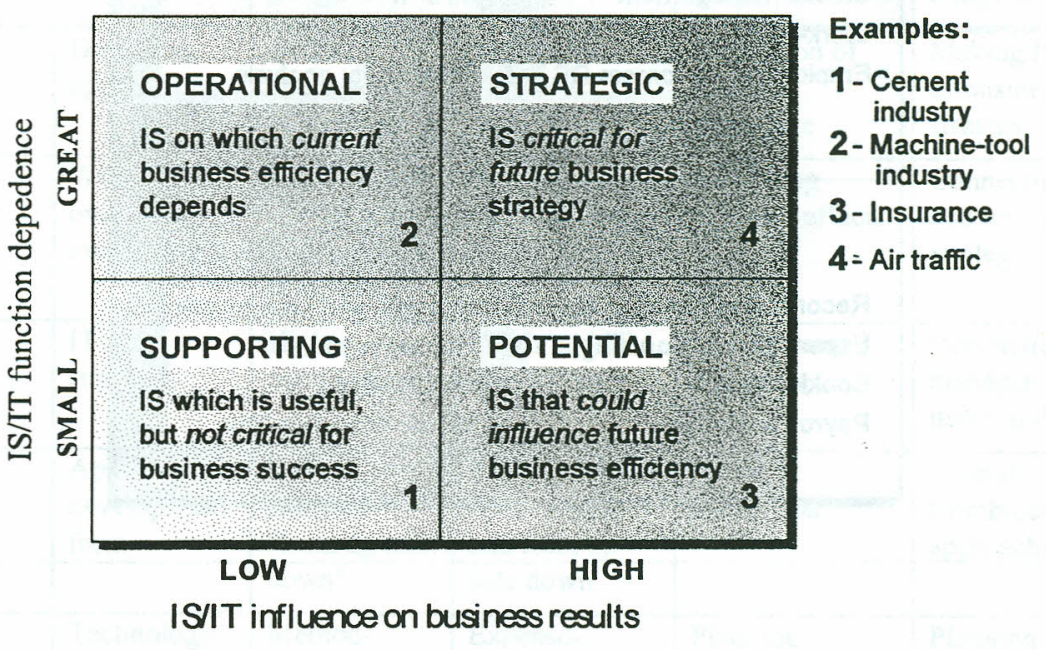

Figure 3. Estimation of IS/It importance for organisation

Depending on the results of the estimation of IS/TT impact, each organisation will determine primary areas for implementing IS/IT, the scope of IS/IT activities, their role in organisation as well as the priorities of IT investment compared to other investments. Thus, the IS development manager of the organisation whose IS is of a 
strategic importance, will be a member of a business board or top management board, whilst in the organisation where IS has only a supporting role, IS/IT activities will be only a part of some operational function.

Regarding the fact that the whole IS is in no organisation a homogenous integrity consisting of the applications of the same importance, the similar analysis like the one described should be applied to all IS subsystems in order to estimate their significance and determine the relative priorities of new IT investments. If the manufacturing firm from the field of machine building industry or electro mechanical industry (supposing they produce components for complex equipment that could, at the same time, be sold to individual buyers which means that they produce following direct orders but also following estimated demand) is being analysed then the whole IS of such firm consists of more subsystems in which the level of used IT has not the same significance. Possible result of the estimation of the significance of IT investment for such organisation is shown in Figure 4.

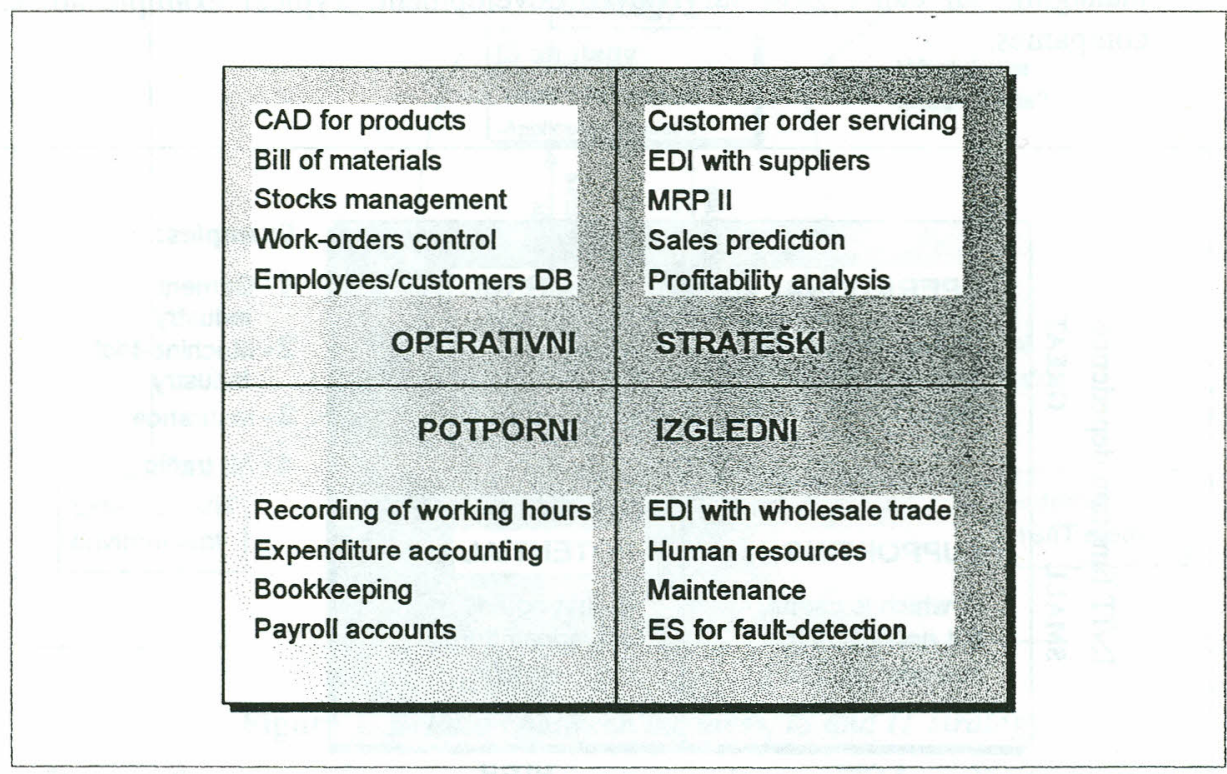

Figure 4. The importance of IS subsystem for manufacturing company

Such analysis in each organisation is the primary step in framing strategic planning of IS development and selecting priorities in new IT investments. There is always a possibility of obtaining different results of analysis in different organisations. Therefore it's surprising to find that several very respectable companies in Croatia, which belong to completely different branches of industry, are implementing the same program-system (as a more expensive and complex part of IT). The fact that one program system gives good results in a particular organisation is not a sufficient 
reason to use it in another especially if they have different business strategies and different manufacturing and business technologies.

\section{The process of IS/IT strategic planing}

Strategic planning of IS and the necessary ITs, although creative and intuitive work, must be a defined process to the extent that organisation management can organise this work, supervise the participants, take active part in the main stages and make adequate decisions. To understand the essence of the process, the model designed by Earl (1993), based on the analysis of planning practice, carried out in 21 organisations in Great Britain, can be of some help. Although the model may seem like a historical survey of different approaches to IT planning, it is of a great importance for the right selection of methods for designing IS/IT strategy in current conditions, especially if the model is linked with the principal IS types, shown in Figure 3. Similarly, by recognising the existing method for selecting IT in a real organisation, we can find out its maturity for profitable use of selected IT. For this reason, in Table 1 we give a brief version of this model, slightly adjusted to suit our needs.

Table 1. Earl's model for the development of IS/IT strategy

\begin{tabular}{|l|l|l|l|l|l|}
\hline Attributes & Stage 1 & Stage 2 & Stage 3 & Stage 4 & Stage 5 \\
\hline Main Task & $\begin{array}{l}\text { Designing } \\
\text { applications }\end{array}$ & $\begin{array}{l}\text { Defining } \\
\text { user's needs }\end{array}$ & $\begin{array}{l}\text { Detailed IS } \\
\text { planning }\end{array}$ & $\begin{array}{l}\text { Estimation of } \\
\text { strategic } \\
\text { advantage }\end{array}$ & $\begin{array}{l}\text { Making IS a part } \\
\text { of business } \\
\text { strategy }\end{array}$ \\
\hline $\begin{array}{l}\text { Principal } \\
\text { objectives }\end{array}$ & $\begin{array}{l}\text { Winning } \\
\text { over the } \\
\text { management } \\
\text { application } \\
\text { priorities }\end{array}$ & $\begin{array}{l}\text { Reconciling } \\
\text { poordinating } \\
\text { functions }\end{array}$ & $\begin{array}{l}\text { Achieving } \\
\text { business effects }\end{array}$ & $\begin{array}{l}\text { Connecting IS } \\
\text { and business } \\
\text { strategy }\end{array}$ \\
\hline $\begin{array}{l}\text { Planning } \\
\text { initiator }\end{array}$ & $\begin{array}{l}\text { IT offer } \\
\text { supply }\end{array}$ & $\begin{array}{l}\text { Higher } \\
\text { management }\end{array}$ & $\begin{array}{l}\text { User's and IT } \\
\text { development }\end{array}$ & $\begin{array}{l}\text { Management } \\
\text { and use's }\end{array}$ & $\begin{array}{l}\text { Reconciled: } \\
\text { management } \\
\text { user's and IT }\end{array}$ \\
\hline $\begin{array}{l}\text { Planning } \\
\text { approach }\end{array}$ & $\begin{array}{l}\text { Application } \\
\text { development } \\
\text { from }\end{array}$ & $\begin{array}{l}\text { Need } \\
\text { analysis } \\
\text { from up side } \\
\text { down" }\end{array}$ & $\begin{array}{l}\text { Balanced: from } \\
\text { down side up } \\
\text { and from up } \\
\text { side down }\end{array}$ & $\begin{array}{l}\text { User's } \\
\text { Inovations }\end{array}$ & $\begin{array}{l}\text { several } \\
\text { Combined } \\
\text { approaches }\end{array}$ \\
\hline $\begin{array}{l}\text { General } \\
\text { characte- } \\
\text { ristic }\end{array}$ & $\begin{array}{l}\text { Technology - } \\
\text { guided } \\
\text { planning }\end{array}$ & $\begin{array}{l}\text { Method- } \\
\text { guided } \\
\text { planning }\end{array}$ & $\begin{array}{l}\text { Expense- } \\
\text { guided } \\
\text { planning }\end{array}$ & $\begin{array}{l}\text { Planning } \\
\text { according to } \\
\text { business } \\
\text { objectives }\end{array}$ & $\begin{array}{l}\text { Planning } \\
\text { according to } \\
\text { strategic goals }\end{array}$ \\
\hline
\end{tabular}

As we can see from the table above, activities at Stage 1 represent the initial form of IS/IT planning in organisation, characteristic of the early EOP development stages which is guided by IT offer, and most often run by IS/IT professionals who are in this business more close to their "natural partners" - software and hardware manufacturers 
(of representatives) than to their management. Technically oriented IS/IT professionals or "shortsighted technologists", as named by Wyman (1985), cannot see that the equipment- manufacturers are offering their products and the results of their work and development, while the organisation must satisfy its information needs in order to survive on the market. Since most organisation have not moved far from the first stage, we may suppose that this is a result of the insufficient effectiveness of IT investment.

The right column of Table 1, marked as Stage 5, describes the characteristics of IS/IT strategic planning. It will be used by organisations that have a clear vision of using modern IT in achieving their strategic goals. Described planning stages are to certain extent connected with the importance of IS for organisation, which is illustrated in Figure 5.

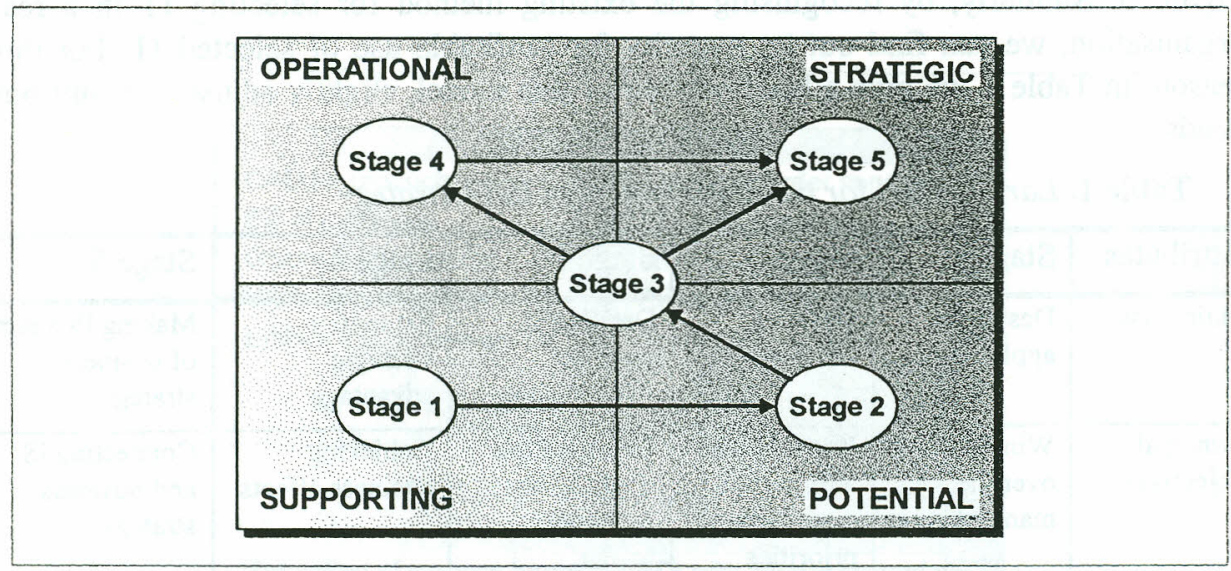

Figure 5. Planning stages according to Earl's model and the importance of IS

The model of IS/IT strategic planning process is illustrated in Figure 6 in the form of a flow-chart. Input factors for the process of planning are defined, approaches, methods and techniques are marked and expected output results are listed.

Input values for the process of IS strategic planning and the use of ITs, according to the above Figure, include:

- External business environment: economic system, market, industry and competition surrounding the organisation.

- Internal business environment: current organisation strategy, business objectives, disposable resources, current and planned organisation management, current and future business technology and current business efficiency. 
- Internal IS/IT environment: current IS and applied ITs and their impact on business managing, current applications, organisation's maturity to accept new IT, knowledge and experience of IS designers.

- External I/IT environment: trends in IT development and their application in other business-partner organisations.

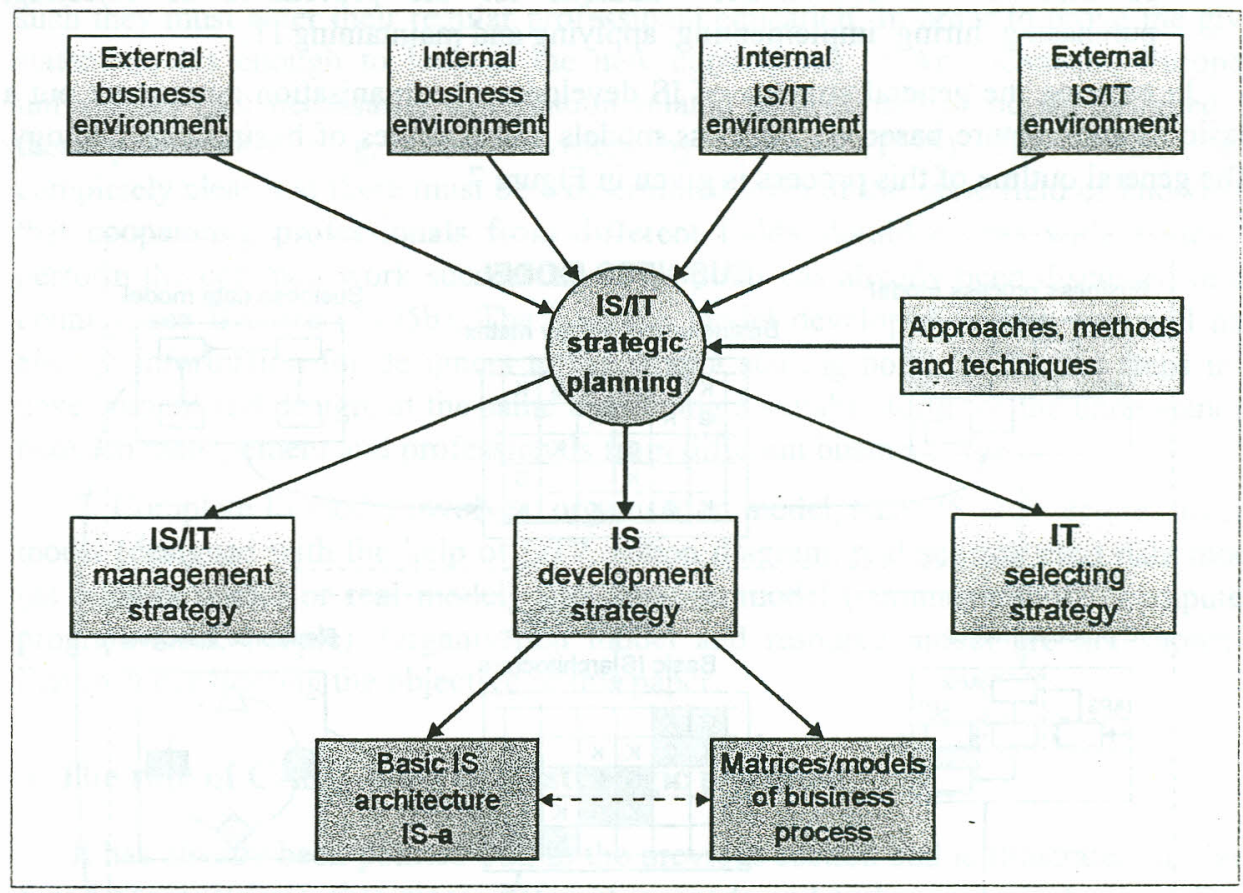

Figure 6. IT/IS strategic planning procedure

For succesful carrying out of IS strategic planning process, the selection of the appropriate approaches, methods and techniques, is of a great importance. There is no unequivocal group of methods and techniques that could be applicable in each case. On the contrary, it is a creative process, combining analytical and formal methods, linking them together and their complementing each other in order to find the most suitable procedure for a particular organisation.

Since the described job requires experience, it is advisable to hire an expert with an extensive knowledge of IS and management.

According to the previous Figure, there are three output results of IS/IT strategic planing:

- IS/IT management strategy includes the general principles and organisational model of IS development process management and design and IT application, 
that will be used in organisation as a consistent business policy. The strategy at this level also includes the decision about the way of providing necessary resources (buying or developing programes, purchasing or hiring equipment).

- IS development strategy defines the methods of analysis and design, standards and procedures for security and quality management and the way in which each business function will develop and apply common IS.

- IT selection strategy issues standards for the procedures of selecting, purchasing, hiring, implementing, applying and maintaining IT.

In creating the general strategy of IS development, organisation must work out a basic IS architecture based on business models and matrixes of business technology. The general outline of this process is given in Figure 7.

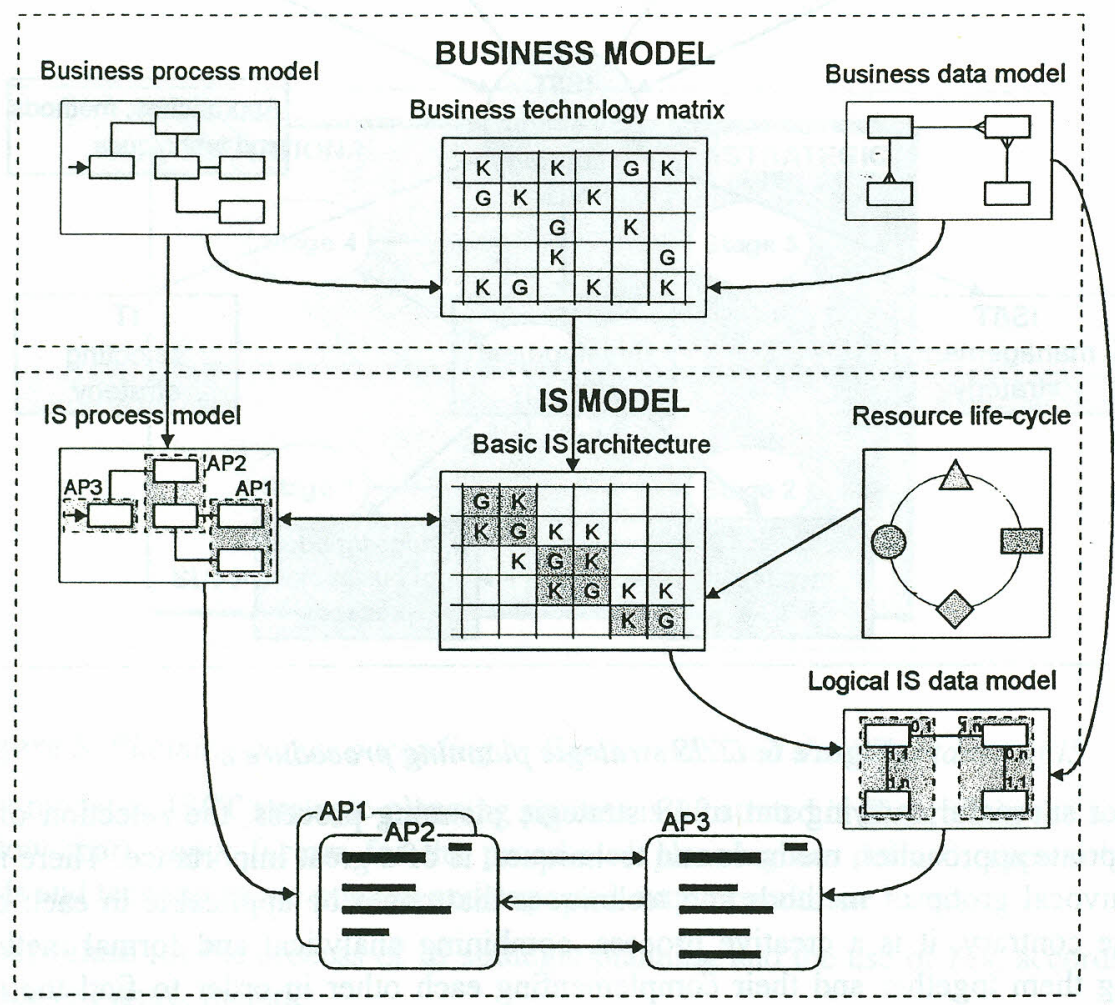

Figure 7. Development of basic IS architecture, as a part of IS strategic planning

Special methods, techniques and algorithms which are used for designing the basic IS architecture, are the topic of an extensive study and are not described in this paper. We shall point out only some general principles of the way this process is carried out:

1. The process is dived into two steps: the first involves business-model designing (carried out y management and best experts from particular business area), while the 
second involves IS model development (carried out by IS designers and after-wards approved by management).

2. In both models, some well-known techniques from the general theory of IS design, e. g. matrix description of IT, data flow-chart and ERA-model for business data, are used. Contrary to the generally accepted opinion that these methods are designed only for IS/IT professionals, is should be stressed that they must be a part of fundamental knowledge of each manager, engineer, economist, lawyer, etc., and as such they must enter their regular professional education. In order to prove the given statement, it's enough to look at the new curriculums of American and European universities (not necessarily information related professions) or books designed for these professions, e. g. a book written by McLeod (1995). Theoretically, it is completely clear that there must be a determined level of the same field of knowledge that cooperating professionals from different fields should posses with a view to perform the common work successfuly. This point has already been discussed in our country, see Brumec (1995b). The business model developed in this way will have enough information for designers to use it as a starting point for further steps in IS development and design, at the same time being a suitable form for the understanding between management and professionals from different business areas.

3. Complete IS model involves: organisation model, basic IS architecture, process model (designed with the help of DTP, action diagram, real scheme etc.) data model (as relation model or real model) and resource model (communications, computers, program-tools, people). Organisation model and resource model are not shown in Figure 7, considering the objective of this paper.

\section{The role of CASE-tools in IS strategic planning}

It has already been pointed out, in the previous section and is illustrated in Figure 6 and particularly 7, that many different methods and techniques can be used for IS strategic planning formalized process. Some of them are used in information related professions in designing and creating IS, that's being the reason they are integrated in so-called "Front-end CASE" (or Upper-CASSE) tools. Therefore we can say that CASE-tools of this type have double-role:

1. Formalizing methods and techniques that can be used for IS/IT strategy planning.

2. Help in development and design of complex ISs.

Much has been written about the role and the way of using CASE-tools, regarding the second issue, from both theoretical and practical point of view. Therefore we shall discuss in more details the possible role of CASE-tools regarding the first issue.

Following the steps in figure 6 and 7, we could define the requirements to which CASE-tools should respond in order to be of any use for IS strategic planning. These requirements can be divided into two main groups: 1) methods and techniques and 2) 
properties of infrastructure. Requirements for integrated methods and techniques are shown in Table 2.

More detailed comparative analysis of "Upper-CASE-tools" which are more available in the market, shows that none of them has all methods and techniques integrated that would completely match the level of these requirements' complexity. AT the same time we can notice that in most of them, the roots of one or more mentioned methods already exist (primarily directed towards the specific needs of IS designers), and they could be extended, in a way to make them more applicable in IS strategic planning.

Table 2. Requirements for extending CASE-tools with IS strategic planning methods

\begin{tabular}{|l|l||}
\hline Methods and techniques & Tasks in IS strategic planning \\
\hline Decomposition diagram & $\begin{array}{l}\text { modelling business objectives and their hierarchies } \\
\text { modelling organisational }\end{array}$ \\
\hline $\begin{array}{l}\text { Multidimensional matrix picture of } \\
\text { weighting entity relations }\end{array}$ & $\begin{array}{l}\text { showing mutual relation between several types of } \\
\text { factors (e. g. depart ments-tasks-locations) }\end{array}$ \\
\hline Structure and value transformation of matrix & $\begin{array}{l}- \text { taking notes of changes in relation between factors } \\
\text { simulating the effects of changes in structural } \\
\text { relation } \\
\text { simulating and estimating effects of reengineering }\end{array}$ \\
\hline Optimization of relations shown with matrix & $\begin{array}{l}- \text { organisational structure optimization } \\
\text { basic IS architecture optimization } \\
\text { database optimization }\end{array}$ \\
\hline $\begin{array}{l}\text { Modelling business } \\
\text { processes for more types of folows }\end{array}$ & $\begin{array}{l}\text { business process reengineering } \\
\text { time and value estimation of business models }\end{array}$ \\
\hline Business data modelling & $\begin{array}{l}\text { data modelling by relational and object-oriented } \\
\text { methods }\end{array}$ \\
\hline $\begin{array}{l}\text { layout and grouping data resources } \\
\text { estimating importance and accessibility of data. }\end{array}$ \\
\hline
\end{tabular}

Regarding infrastructure-requirements, it is important to have a repository (encyclopedia) for storing all relevant data about system, with the possibility of logical searching, good text and graphic presentation and documentation. Such repository should enable simultaneous work of a number of experts working on IS strategic planning. Further-more, the requiredCASE-tool for supporting SPIS, should be compatible with other program tools, e. g. project planning, cost analysis etc. most modern "Upper-CASE" tools, especially those in. Windows, meet these requirements.

\section{Conclusion}

By examining the problem of the effectiveness of introducing and applying new IT, a conclusion has been reached that the prerequisites for the effectiveness are created at the early stages of IS development by connecting IS/IT strategy with 
business strategy. The approach to IS strategic planning reflects the organisational maturity of a company for using the modern ITs. Different companies cannot expect the same effect from ITs, nor is the effect equal in different buskins areas within the same company. Numerous researches in the world have confirmed that such assumptions are justified, while in our country systematic researches in this filed still need to be carried out. The process of IS/IT strategic planning can be partly formalized. Some of the usable methods and techniques can be found in some existing "Upper-CASE" tools which, for this purpose, should be extended and supplemented, conforming to the requirements that result from the very nature of this job.

\section{References}

1. Ansoff, I.H. (1968) Corporate Strategy, Penguin Press, Hammondsworth.

2. Berndt, E.R., Morrison, C.J. (1990) Assessing the productivity of information technology equipment in U.S. manufacturing industry, Annual Meeting of the American Economic Association (prilog pod oznakom AEA1990), Washington, DC.

3. Brumec, J. (1995) Ulaganje u informacijske tehnologije - izazov, dvojba i zamka, Infotrend 32(3).

4. Brumec, J. (1996) Prilog općoj taksonomiji informacijskih sustava, 7.međunarodni simpozij "Informacijski sustavi", Zbornik radova str 95-105, Varaždin.

5. Currie, W. (1995) Management Strategy for IT-An International Perspective, Pittman Publishing, London.

6. Daniels, N.C. (1994) Information Technology - The Management Challenge, Addison-Wesley, New York.

7. Earl, M.J. (1989) Management Strategies for Information Technology, Prentice Hall, Englewood Cliffs, NJ.

8. Earl, M.J. (1993) Approaches to strategic information systems planning: experience in 21 UK companies, MIS Quarterly, 17(1).

9. Griffiths, C., Willcocks, L. (1994) Are major technology projects worth the risk? u Proceedings of the 2nd European Conference on IT Evaluation, Henley, July.

10. Hammer, M., Champy, J. (1994) Reeingineering the Corporation - A Manifesto for Business Revolution, HarperCollins Publishers, New York.

11. Hochstrasser, B. (1990) Evaluating IT investments - matching techniques to projects, Journal of Information Technology 5(4).

12. Krakar, Z. (1996) Efekt paradoksa, Infotrend 51(10).

13. Johnson, G., Scholes, K. (1993) Exploring Corporate Strategy; Text and Cases (3rd edn.), Prentice-Hall, Englewood Cliffs, NJ. 
14. McFarlan, F.W. (1984) Information technology changes the way you compete, HBR, March/April.

15. McLeod, R. (1996) Management Information Systems (6th edition), Macmillan Publishing, New York.

16. Mintzberg, H., Quinn, J. (1991) The Strategy Process, Prentice-Hall, Englewood Cliffs, NJ.

17. Peppard, J. (1993) IT Strategy for Business, Pittman Publishing, London.

18. Robson, W. (1997) Strategic Management \& Information Systems, Pittman Publishing, London.

19. Ward, J., Griffiths, P. (1996) Strategic Planning for Information Systems, John Wiley, Chicester.

20. Willcocks, L. (ed.) (1994) Information Management - The Evaluation of Information Systems Investments, Chapman \& Hall, London.

21. Wyman, J. (1985) Technological myopia, Sloan Management Review, Winter.

Received: $1997-08-22$

Brumec J. Strateško planiranje informacijskih sustava

\section{Sažetak}

Strateško planiranje informacijskih sustava je posljednjih godina izazovna tema za znanstvenike $i$ praktičare, koji se bave razvojem informacijskih sustava (IS) i primjenom informacijskih tehnologija (IT) u poslovnim sustavima. Recentna istraži-vanja ukazuju na opću pojavu, da je učinak IT na efektivnost poslovnih sustava znatno ispod očekivanog, pa stoga razvoj IS i primjena IT nije više samo posao informatičara, nego i suštinski problem za upravu poduzeća. U radu se postavlja hipoteza da uspješnost primjene IS zavisi o strateškom planiranju, kao prvom koraku njegovog životnog ciklusa. Također se nude neka promišljanja o tome kako prepoznati mogući ućinak IS/IT na poduzeće i osigurati da ulaganje u IT ne bude poslovni rizik, već poduhvat s visokom vjerojatnošću postizanja dobrog poslovnog uspjeha.

Ključne riječi: strateško planiranje, informacijski sustav, informacijske tehnologije. 